DOI: https://doi.org/10.24127/ajpm.v10i2.3451

\title{
LEARNING EFFECTIVENESS THROUGH VIDEO PRESENTATIONS AND WHATSAPP GROUP (WAG) IN THE PANDEMIC TIME COVID-19
}

\author{
Kadek Adi Wibawa ${ }^{1 *}$, I Putu Ade Andre Payadnya ${ }^{2}$ \\ ${ }^{1 *, 2}$ Universitas Mahasaraswati Denpasar, Denpasar, Indonesia \\ *Corresponding author. \\ E-mail: $\quad \frac{\text { adiwibawa@unmas.ac.id }}{\text { adeandre@unmas.ac.id }}^{\left.{ }^{2}\right)}$
}

Received 04 January 2021; Received in revised form 16 June 2021; Accepted 01 July 2021

\begin{abstract}
This study aims to determine the effectiveness of learning through video presentations and Whatsapp Group (WAG) on the topic of vector space during the Covid-19 pandemic. The learning system is carried out online using videos developed and shared via WAG. This research is action research conducted in two cycles with each cycle consisting of four meetings. The subjects of this research were 14-second semester students in the Mathematics Education Study Program Faculty of Teacher Training and Education, Universitas Mahasaraswati Denpasar who took Linear Algebra courses. The data collected in this study were the researcher's actions, the results of the evaluation, and student responses to the video presentation and WAG applied by the researcher. The results of this study indicate that the application of video presentations and WAG on the topic of vector space during the Covid-19 pandemic was classified as effective, because the average student score increased $12.9 \%$ and $1.3 \%$ respectively with the class average before the action 68 , after the action in cycle I 76.79 and after the action in cycle II 77.79. Student responses regarding the application of video presentations and WAG were very positive. This learning strategy can be used as a solution during the Covid-19 pandemic, which requires students and lecturers to carry out the teaching and learning process from home.
\end{abstract}

Keyword: Video presentations; whatsapp group (WAG); vector space; online learning.

\begin{abstract}
Abstrak
Penelitian ini bertujuan untuk mengetahui efektifitas pembelajaran melalui video presentasi dan WAG pada topik ruang vektor di masa pandemi Covid-19. Sistem pembelajaran dilakukan secara daring dengan menggunakan video yang dikembangkan dan dibagi melalui WAG. Penelitian ini merupakan penelitian tindakan yang dilaksanakan dalam dua siklus dengan masing-masing siklus terdiri dari empat pertemuan. Subjek penelitian ini sebanyak 14 mahasiswa semester II di program studi pendidikan matematika FKIP Universitas Mahasaraswati Denpasar yang mengambil mata kuliah Aljabar Linear. Data yang dikumpulkan dalam penelitian ini adalah tindakan peneliti, hasil evaluasi dan respon mahasiswa terhadap video presentasi dan WAG yang diterapkan peneliti. Hasil penelitian ini menunjukkan bahwa penerapan video presentasi dan WAG pada topik ruang vektor di masa pandami Covid-19 tergolong efektif, karena rata-rata nilai mahasiswa mengalami peningkatan berturut-turut 12,9\% dan 1,3\% dengan rata-rata kelas sebelum tindakan 68, setelah tindakan pada siklus I 76,79 dan setelah tindakan pada siklus II 77,79. Respon mahasiswa tentang penerapan video presentasi dan WAG sangat positif. Strategi pembelajaran ini dapat dijadikan solusi di masa pandemi Covid-19 yang mengharuskan mahasiswa dan dosen melaksanakan proses belajar mengajar dari rumah.
\end{abstract}

Kata Kunci: Video presentasi; whatsapp grup; ruang vektor; pembelajaran daring.

This is an open access article under the Creative Commons Attribution 4.0 International License

\section{INTRODUCTION}

Before the Covid-19 pandemic, learning was done face-to-face in class. Several variations are made by educators to increase the effectiveness of learning, such as implementing learning strategies that are tailored to the character of students, applying various learning media, such as power points, modules and others. Although the use of technology has been so massive in Indonesia, educators still use 
conventional learning approaches by utilizing textbooks and power points. This kind of learning was also carried out by researchers before Covid-19 occurred.

In March 2020 the Indonesian government officially announced that the teaching and learning process was carried out from home. At that time, many educators including lecturers had not prepared a proper learning system to be implemented. Lecture obtained a lot of information, including lecturers using group Whatsapp media to conduct learning, some lecturers used the Management Learning System (MLS) provided by Google, namely Google Classroom, and some used virtual learning through zoom meetings and google meet (Engelbrecht, Llinares, \& Borba, 2020; Irfan, Kusumaningrum, Yulia, \& Widodo, 2020; König, JägerBiela, \& Glutsch, 2020; Mailizar, Almanthari, Maulina, \& Bruce, 2020; Moreno-Guerrero, Aznar-Díaz, Cáceres-Reche, \& Alonso-García, 2020; Mulenga \& Marbán, 2020a, 2020b; Wargadinata, Maimunah, Dewi, \& Rofiq, 2020; Wiratomo \& Mulyatna, 2020). The researcher feels that each of these media has very significant weaknesses. Moreover, some media are only used by lecturers to share material, give assignments, and collect assignments. There is no process of explaining or providing meaningful stimuli for students.

The phenomenon that occurs in the classroom in the vector space course is that students have low learning outcomes with an average of 68 out of a total score of 100 . The learning carried out by the Lecturer focuses on Howard Anton's textbook on Elementary Linear Algebra, in addition to explaining the material using this book., the lecturer makes several power points to explain the material, and displays it in front of the class. When students have difficulty, students will ask questions and the lecturer will repeat the explanation given. At that time, students seemed to understand the material, but after an evaluation, it turned out that student learning outcomes were still very low. Especially when the Covid-19 pandemic occurred, lecturers thought about learning innovations that could be done, the purpose of which was not only adapting to the situation but also being able to overcome problems that previously occurred. So the researchers thought of a solution by implementing learning using video presentations, then sharing them on Whatsapp groups and discussing them with students and lecturers.

The researcher took the initiative to create an innovative lesson through video presentations. Video presentations have advantages including that they can be seen directly by students wherever they are, can be repeated if there is an explanation that is not understood and can be played anytime and anywhere according to student wishes. With these advantages, it is hoped that effective learning can be created. Various things need to be prepared to make learning effective through video presentations. First, videos are made before learning begins. Second, the explanation is short, concise, and clear. Third, the voice must be heard clearly. Fourth, the video display must be attractive so that students are interested and not bored in following the lesson. Lecture also prepare whatsapp groups as a medium for discussion if there are explanations that are not yet understood.

Learning through video presentations has been carried out by several lecture (Djamilah \& Lazwardi, 2020; Mustakim, 2020) To implement 
learning using video presentations, it is necessary to pay attention to several things such as 1) providing concise learning materials, 2) minimizing sending material in the form of heavy videos to save the quota, 3) selecting material in the video must be based on language criteria that are easy to understand, 4) still providing material before the assignment, 5) giving varied and different questions for each student, 6) giving assignments according to the lesson schedule, 7) reminding when there are assignments, and 8) reducing assignments (Mustakim, 2020). Several things stated by (Mustakim, 2020) became the attention of lecture to develop the video used in this study. The use of instructional videos is very effective in increasing student understanding of learning mathematics (Djamilah \& Lazwardi, 2020).

In communicating directly and quickly with students, lecturers can do it via whatsapp group (WAG). WAG can help students communicate and discuss directly with lecturers and other students (Abdillah, 2020; Khusaini, Suyudi, Winarto, \& Sugiyanto, 2017; Purnama, 2020; Susilowati, 2021). Further (Khusaini et al., 2017) found that the role of WAG was very effective in terms of conducting assessments both by lecturers and peers. The online learning model using WhatsApp Groups is slightly better than using Google Classroom by paying attention to the technical/system applied during the learning process (Susilowati, 2021).

This study focuses on vector space material which is part of the linear algebra course. The topic of vector space is a material that is difficult for students to understand because it is very abstract, contains deductive proofs, and involves a lot of operations between variables. Last semester, the average score of students obtained was low, namely 68 . The average was obtained based on the results of the final semester examinations of students in the Mathematics Education Study Program of the Faculty of Teacher Training and Education at Universitas Mahasaraswati Denpasar. This happens when learning is done face to face in class. What about when the Covid-19 pandemic occurs? Can effective learning be achieved? That is the purpose of this research, to find out effective learning is through video presentations on the topic of vector space during the Covid-19 pandemic.

\section{METHOD}

The design of this research is action research by developing instructional videos in two forms. The first form are learning videos with presentation slides, and facial expressions. The process of making this video begins by making material on a power point, then recording on zoom meetings that are connected to the internet, after that edit on the Filmora application by adding music and adjusting the researcher's voice to make it clear. The second form, instructional videos with the appearance of the researcher explaining the material on the blackboard. The process of making this video begins with making a systematic scenario of the presentation of the material, then it is explained through a whiteboard recorded using a mobile phone, after which it is edited using the Filmora application by adding music, adding words or sentences to emphasize important things, zooming in and zooming. out, as well as adjusting the researcher's voice so that it can be heard clearly. 
DOI: https://doi.org/10.24127/ajpm.v10i2.3451

The subjects of this study were 14 students of semester III class 2019/2020 who took Linear II Algebra courses. This research was conducted in some cycles for 2 months (may - June 2020), each cycle consisting by four actions. Each cycle, stages are carried out starting from planning, implementation, observation and reflection. It can be seen in Figure 1.

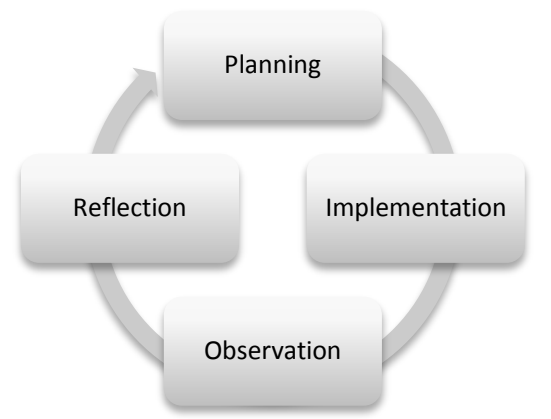

Figure 1. Four actions for each cycle

In planning, researchers prepared lesson plans, video presentations about vector space, formed Whatsapp groups, made lecturer and student observation sheets, made evaluation instruments for each cycle, answer keys, assessment rubrics, and google forms to find out student responses. Next, the researcher implemented the plan using video presentations and WAG. After the action was taken, the researcher collected the results of observations made on lecturers and students. This result is then used as a reflection to move on to the next cycle.

Data analysis was carried out qualitatively and quantitatively. Qualitatively, lecture describe teacher actions and student responses. Quantitatively, the researcher describes the results of the student tests. Data analysis techniques were carried out qualitatively and quantitatively. Qualitatively, students' questions were analyzed through Whatsapp groups and student statements via google form by reducing data by paying attention to the meaning and suitability of questions and statements with the topic being discussed. Quantitatively, using the class average calculation.

$$
\bar{x}=\frac{\sum f x}{n}
$$

Information

$\bar{x}$ : Mean

$\sum f x:$ Sum of all values

$n$ : Number of students

Student scores are divided into five categories that follow the assessment system at Mahasaraswati University Denpasar. The five categories are $80-100$ (very good), 70 - 79 (good), 50 - 69 (enough), 40 - 59 (poor), and 39 (very poor). Learning criteria are said to be effective if the average student is more than 70 or at least in the Good category, and there is an increase in value from before the research was carried out to an increase in each cycle.

\section{RESULT AND DISCUSSION}

The lecture's action begins with making two forms of video, namely a learning video with presentation slides and facial expressions, and a learning video with the appearance of the researcher explaining the material on the board. This video is uploaded directly on WhatsApp Group and some are uploaded on the researcher's YouTube channel "Mr. Kadek "and shared the video link on the WhatsApp group. The topics discussed by the lecture in the video are 1) Introduction to Vectors, 2) Operations in 2D and 3D Vector Spaces, 3) Euclid-n-Space and Vector Space, 4) Proof of a $2 \times 2$ Matrix is a Vector Space, 5) A Non-Vector Space Set, 6) Subspace Vector, and 7) Linear Combination. 
DOI: https://doi.org/10.24127/ajpm.v10i2.3451

At the first meeting, the lecture distributed a video presentation on WAG with the theme Introduction to Vector. "The material according to the contract is VECTOR AND SUB VECTOR ROOM. Before you discuss that at the next meeting, you want to review the material about Vector first. You oblige you to download, watch and record important things in the video above ". Lecture want to check students' understanding of vectors that have been studied in high school and previous courses. Introduction to Vector is a prerequisite for understanding vector space and vector subspace. After allowing students to watch the video, the researcher asked the students to do their assignments and sent them to email.

At the second meeting, the researcher uploaded a presentation video with the theme Operation in 2D and 3D Vector Spaces on the YouTube channel "Mr. Kadek" then shared the link on the WAG. Lecture applied the same pattern, namely, after watching the video the researcher asked students to do the tasks in the video and sent them to the lecture' email. Lecture upload videos on YouTube because the video size is large enough not to allow it to be uploaded on the WAG.

At the third meeting, the researcher started the lesson by reviewing the previous material by asking "... Try to share in the form of a photo in this group, the geometric representation of the vector $\mathrm{u}(1, \mathrm{x})$ where $\mathrm{x}$ is the last digit of your respective NPM". Of the 10 subjects, all responded by giving the correct answer. Then the researcher proceeded to the core material by sharing the presentation video with the topic Euclid-n-Room and Vector Room which was previously uploaded on the
Researcher's YouTube Channel. After watching the video, the researcher asked students to work on the questions and share the answers to the WAG. During the process of watching videos and completing assignments, students encountered obstacles, such as: "Sorry, sir. I want to ask, can you clarify for the axiom that does not fulfill that, sir? For example in axiom 7, for $u \_2+v \_2$ why is the result 0 ? Please clarify, sir ". The second question is "Sorry beforehand sir, I want to ask about this matter of proof. Could you please explain again, sir? I don't understand how the stages of completion are". To answer this question reserchers created a new video entitled Sets Not Vector Space because the operation times are weird. After the students listened to the researcher's explanation via video, the students tried to do the assignment again, and it turned out that something was wrong. Lecture clarify again by correcting student work and making videos again to clarify the topic being asked. Students are very active in providing answers to the WAG, and I provide corrections to the mistakes made. And finally, students are able to overcome their mistakes and find the correct answer.

The fourth meeting is an evaluation of learning outcomes after 3 meetings using video presentations. The evaluation results can be seen in Table 1 .

Table 1. Results of evaluation i learning through video presentations and WAG

\begin{tabular}{clcc}
\hline No & Initial Name & Score & Category \\
\hline 1 & DAPS & 75 & Good \\
2 & AIAU & 60 & Enough \\
3 & AD & 78 & Good \\
4 & IKMR & 65 & Enough \\
5 & IM & 85 & Very Good \\
6 & ADL & 85 & Very Good \\
7 & DPP & 60 & Enough \\
8 & PK & 75 & Good \\
9 & RKA & 90 & Very Good \\
\hline
\end{tabular}


DOI: https://doi.org/10.24127/ajpm.v10i2.3451

\begin{tabular}{clcc}
\hline No & Initial Name & Score & Category \\
\hline 10 & NKM & 75 & Good \\
11 & VAW & 85 & Very Good \\
12 & IG & 80 & Very Good \\
13 & MCM & 82 & Very Good \\
14 & AL & 80 & Very Good \\
\hline Average & 76,79 & Good \\
\hline
\end{tabular}

Based on the results of first evaluation, it appears that there are 11 people get a minimum score in the good category and get good enough or low scores as many as 3 people. The average evaluation results increased compared to the average during the first evaluation of $12.9 \%$. This shows that learning using video presentations and WAG is effective because it can increase the class average score.

After the evaluation is performed two reflection techniques, namely 1) field notes from lecture regarding the shortcomings of lecture in carrying out learning, 2) asking students through www.mentimeter.com. Based on the results of reflection, the researcher realized that the interaction between lecture and students was lacking in discussing the questions/material on the WAG. Apart from the limited conditions of the WAG for writing mathematical answers, lecture also lacked time management, so the discussion of questions was not optimal. The second drawback, namely the researcher's learning pattern tends to be monotonous which results in students getting bored in receiving the material. However, the video presentation made has been edited and added music so that it looks quite attractive. From students there were various responses, some felt there were no obstacles during the learning that was carried out and the explanation from the video was easy to understand. Some students conveyed that the material was difficult to understand, the lecture' answers were less detailed so that the understanding of what was being asked was lacking, and there were fewer examples of questions on each topic discussed. Based on the results of the lecture' reflection, the researcher made improvements by 1) increasing the intensity of the interaction on the WAG and 2) making the presentation video more detailed and clear with more varied examples of questions.

Meeting $5^{\text {th }}$ lecture discuss and discuss student answers during evaluation. The lecture asked the students through the WAG "This is one of the results of the evaluation (dividing picture 1 in the WAG), number 4 has not been answered, but the good thing is that it can replace $x$ correctly (before $k(u, v)=(x k u, x k v)$, student replaces the value of $x$ by using the last number of his identity). Anyone can help to work on this problem?" (Figure 2)

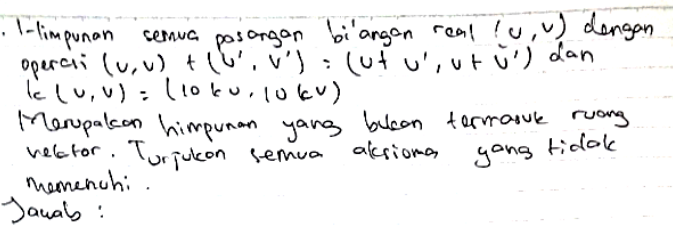

Figure 2. Answers of students who have difficulty working on evaluation questions I

Through this picture, the lecturer said that some of the questions above did not answer. Then the lecturer triggers the discussion and students' critical thinking by asking.

Lecture: "Can anyone answer?". Because no one volunteered, the lecture directly appointed two students to respond to the above problems by mentioning the two students.

Lacture: "@Putra Kurniawan and @ Vidia, is a set with addition 
DOI: https://doi.org/10.24127/ajpm.v10i2.3451

and multiplication operations as shown in the picture, a vector space or not?"

Both answered no.

Lecture: "Okee ... What axioms are there to suspect?"

Vidia : "Axiom 7, 8, 9, 10 pack"

Putra : "10 pack axiom".

The researcher immediately asks students to work according to the suspected axiom to determine that the statement in Figure 1 is not a vector space. Lecture use WAG to discuss and discuss all evaluation questions that have been done by students. The results of the researcher's work are captured and shared on the WAG for comment. At the end of this meeting, the researcher ensures that all students are aware of the mistakes made and know and understand the correct answer to each of the questions given.

In the $6^{\text {th }}$ meeting the lecture uploaded a presentation video with the theme Sub-Vector Room on the youtube channel "Mr. Kadek "then shared the link on the WAG. The researcher asked the students according to the following sentence: "Today's material is SUBRUANG vector. Please see the material in this video and do the job ". After listening to the explanation of the video and answering the assignment given, students shared their answers to the WAG. Lecture provide comments and discuss the answers given until students understand the material described.

In the $7^{\text {th }}$ meeting the lecture uploaded a presentation video with the theme Linear Combination on the youtube channel "Mr. Kadek "then shared the link on the WAG. After listening to the explanation on the video presentation that I have shared, the researcher asks students to do the assignments in the video. Lecture provide comments and discuss the answers given until students understand the material described.

The $8^{\text {th }}$ meeting is an evaluation of learning outcomes after 3 meetings using video presentations. The evaluation results are as Table 2 .

Table 2. Evaluation results II learning through video presentations and WAG

\begin{tabular}{clcc}
\hline No & Initial Name & Score & Category \\
\hline 1 & DAPS & 78 & Good \\
2 & AIAU & 70 & Good \\
3 & AD & 75 & Good \\
4 & IKMR & 70 & Good \\
5 & IM & 90 & Very Good \\
6 & ADL & 80 & Very Good \\
7 & DPP & 66 & Enough \\
8 & PK & 78 & Good \\
9 & RKA & 70 & Very Good \\
10 & NKM & 72 & Good \\
11 & VAW & 86 & Very Good \\
12 & IG & 85 & Very Good \\
13 & MCM & 86 & Very Good \\
14 & AL & 83 & Very Good \\
\hline Rata-rata & 77,79 & Good \\
\hline
\end{tabular}

Based on the results of second evaluation, it appears that those who get the minimum score in the good category increase to 13 people and get good enough or low scores as many as 1 person. The average evaluation results increased compared to the average faceto-face class of $1.3 \%$. This shows that learning using video presentations and WAG results from reflection on action is effective.

In completing this research, the lecture asked students to respond to the implementation of Linear Algebra lectures, especially in discussing Vector Space and Sub Vector Space through video presentations and WAG. The student's response can be seen in Figure $3 \mathrm{a}$ and $3 \mathrm{~b}$. 
DOI: https://doi.org/10.24127/ajpm.v10i2.3451
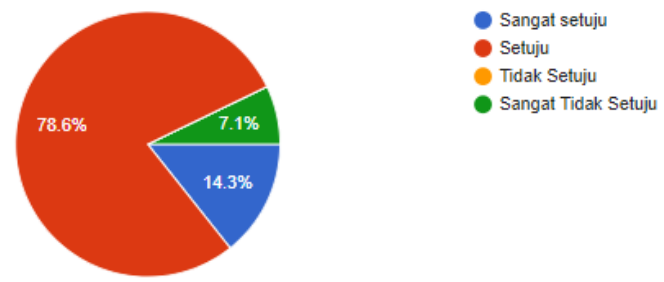

Figure 3a. Learning through video presentations and WAGs was interesting and fun for me.
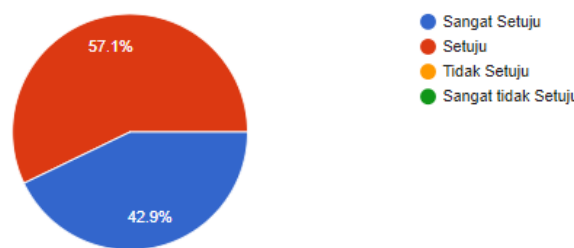

Figure $3 b$. Learning through video presentations and WAGs is useful for me

Figure $3 \mathrm{a}$ shows that there are $14.3 \%$ of students strongly agree that learning through video presentations and WAG is interesting and fun, then $78.6 \%$ agree and $7.1 \%$ strongly disagree. The percentage of students who agree that learning is interesting and fun is greater than those who disagree. Based on the results of student searches who disagree, because of the package/internet factor. This was conveyed by the student that "it costs more money with videos. Why is that, according to me face-to-face will not spend as much quota as we watch videos ". Meanwhile, Figure $3 \mathrm{~b}$ shows that as many as $42.9 \%$ of students strongly agree that learning through video presentations and WAG is useful and $57.1 \%$ agree. This positive response was reinforced by the student's statement, namely "With the existence of learning through video presentations and WAG because of the covid-19 this makes the learning atmosphere more interesting and gets a lot of knowledge" as Figure $4 a$ and Figure $4 b$.

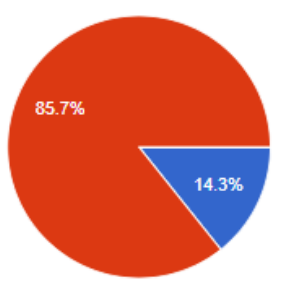

Sangat setuju Setuju Tidak Setuju - Sangat tidak Setuju

Figure 4a. Learning through video presentations and WAGs makes it easy for me to learn.

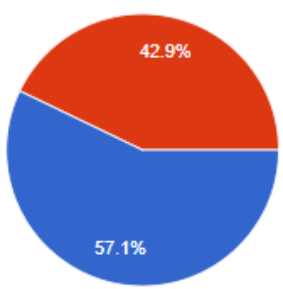

Sangat setuju - Setuju Tidak setuju - Sangat tidak setuju

Figure $4 \mathrm{~b}$. Learning through video presentations and WAGs allows me to repeat explanations if I don't understand them.

Figure 4a shows that as many as $14.3 \%$ of students strongly agree that learning through video presentations and WAG can make learning easier and as many as $85.7 \%$ agreed about it. Beside that, Figure $4 \mathrm{~b}$ shows that as many as $57.1 \%$ of students strongly agreed that learning through video presentations and WAG allowed them to repeat explanations if they did not understand and $42.9 \%$ agreed about it.

This result was confirmed by the student's statement, namely: "if there is a material that is not suitable, it can be seen again in the explanation that has been given". Another student also explained that "the learning that is applied is very effective because the video is presented easily and if we forget or we don't understand about the materials we can repeat the video". This result or conditions are approved by Figure 5a and Figure 5b. 
DOI: https://doi.org/10.24127/ajpm.v10i2.3451

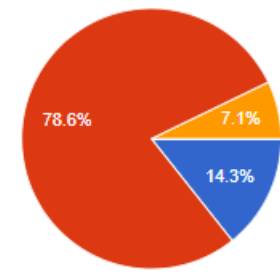

- Sangat setuju

- Setuju

Tidak setuju

- Sangat Tidak Setuju

Figure 5a. Learning through video presentations and WAG increased my learning achievement (understanding of the material and ability to solve questions).

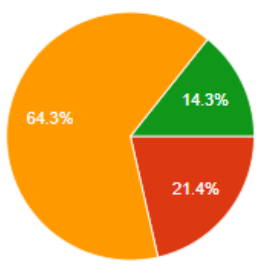

- Sangat setuju - Setuju Tidak Setuju Sangat Tidak Setuju

Figure 5b. The explanation from the speaker on the learning video is difficult to understand

Figure 5a shows that as many as $14.3 \%$ of students stated that learning through video presentations and WAG increased learning achievement (understanding of the material and ability to solve questions) and as many as $78.6 \%$ agreed. This is indicated by the results of evaluations I and II which are mostly above the average. There were $7.1 \%$ who disagreed that their performance had increased. Figure $5 \mathrm{~b}$ shows that as many as $14.3 \%$ of students strongly disagreed if the explanations and presenters (lecture) on the learning video were difficult to understand and as many as 64.3\% expressed disagreement. This result was confirmed by the student's statement, namely: "Learning through video presentations and WAG made me better understand the explanation of the material presented because I can repeat the explanation if I don't understand it and the explanation is also simple and easy to understand". This result is reinforced. There are
$21.4 \%$ of students who agree that the explanation of the speaker is difficult to understand, this is because the variation of the questions presented is lacking.

The results of this study are in line with (Djamilah \& Lazwardi, 2020) what was conveyed by that learning using video presentations is very effective and attracts students' interest to study independently. Coupled with the use of WAG, according to (Khusaini et al., 2017) which students can conduct assessments directly through WhatsApp and can see input instantly without having to wait a long time. This also happens in this study that students can immediately find out the answers submitted and make an assessment of the answers given.

The application of learning videos and WAG can improve student learning independently. This is in line with the statement (Suteja, Guritno, Wardoyo, \& Ashari, 2011) is the presence of an online learning system is expected to increase the intensity of independent learning. So that, one way to help achieve goals that lead to success in online-based independent learning studies can be developed pedagogical frameworks using online social media ( $\mathrm{Li}, 2017)$. In this independent learning, there are levels including 1) personal information management, 2) social interaction and collaboration, and 3) aggregation and information management (Abidah, Hidaayatullaah, Simamora, Fehabutar, \& Mutakinati, 2020; Reinhardt, 2019).

\section{CONCLUSION AND SUGGESTION}

The conclusion of this research is that learning using video presentations and WhatsApp groups on the topic of vector space during the covid-19 pandemic is effective, which is 
indicated by an increase in student learning outcomes from before this research was carried out and in each cycle. Through student responses, which were strengthened by statements from students, it showed that learning was very interesting, fun and useful. In addition, students also stated that it was easier for them to learn because they could repeat the material if they did not understand it. And another finding is that video learning students are not too difficult to understand, students can understand well and feel an improvement in themselves in understanding the topics discussed.

Based on the results of this study, it is recommended that educators use video presentations and whatsapp groups for learning mathematics during the pandemic or online learning. Students are more interested in mathematical material that is explained directly by their educators than explained by other educators, so that educators are expected to have the ability to make video presentations independently. In future research, it is hoped that lecture can combine learning videos in a learning management system (LMS) and examine how students respond and improve their learning outcomes.

\section{REFFERENCES}

Abdillah, M. A. (2020). Analisis Pemanfaatan Media Sosial Whatsapp Group (WAG) Dalam Pembelajaran Matematika SMA di Masa Pandemi Covid-19. Seminar Nasional Pendidikan dan Ilmu Matematika. Universitas Islam Malang. 237-241.

Abidah, A., Hidaayatullaah, H. N., Simamora, R. M., Fehabutar, D., \& Mutakinati, L. (2020). The Impact of Covid-19 to Indonesian Education and Its Relation to the
Philosophy of "Merdeka Belajar." Studies in Philosophy of Science and Education, 1(1), 38-49. https://doi.org/10.46627/sipose.v1i1 .9

Djamilah, S., \& Lazwardi, A. (2020). Pembelajaran Daring Struktur Aljabar dan Analisis Real Pada Masa Pandemi. JARTIKA Jurnal Riset Teknologi Dan Inovasi Pendidikan, 3(2), 403-409. https://doi.org/10.36765/jartika.v3i 2.304

Engelbrecht, J., Llinares, S., \& Borba, M. C. (2020). Transformation of the mathematics classroom with the internet. ZDM - Mathematics Education, 52(5), 825-841. https://doi.org/10.1007/s11858020-01176-4

Irfan, M., Kusumaningrum, B., Yulia, Y., \& Widodo, S. A. (2020). Challenges During the Pandemic: Use of E-Learning in Mathematics Learning in Higher Education. Infinity Journal, 9(2), 147. https://doi.org/10.22460/infinity.v9i 2.p147-158

Khusaini, K., Suyudi, A., Winarto, W., \& Sugiyanto, S. (2017). Optimalisasi Penggunaan WhatsApp dalam Perkuliahan Penilaian Pendidikan Fisika. Jurnal Riset Dan Kajian Pendidikan Fisika, 4(1), 1. https://doi.org/10.12928/jrkpf.v4i1. 6462

König, J., Jäger-Biela, D. J., \& Glutsch, N. (2020). Adapting to online teaching during COVID-19 school closure: teacher education and teacher competence effects among early career teachers in Germany. European Journal of Teacher Education, 43(4), 608-622. https://doi.org/10.1080/02619768.2 020.1809650

Li, V. (2017). Social Media in English Language Teaching and Learning. International Journal of Learning and Teaching, 3(2), 148-153. 
DOI: https://doi.org/10.24127/ajpm.v10i2.3451

https://doi.org/10.18178/ijlt.3.2.148 $-153$

Mailizar, Almanthari, A., Maulina, S., \& Bruce, S. (2020). Secondary school mathematics teachers' views on elearning implementation barriers during the COVID-19 pandemic: The case of Indonesia. Eurasia Journal of Mathematics, Science and Technology Education, 16(7). https://doi.org/10.29333/EJMSTE/8 240

Moreno-Guerrero, A. J., Aznar-Díaz, I., Cáceres-Reche, P., \& AlonsoGarcía, S. (2020). E-learning in the teaching of mathematics: An educational experience in adult high school. Mathematics, 8(5). https://doi.org/10.3390/MATH8050 840

Mulenga, E. M., \& Marbán, J. M. (2020a). Is covid-19 the gateway for digital learning in mathematics education?

Contemporary Educational Technology, 12(2), 111. https://doi.org/10.30935/cedtech/79 49

Mulenga, E. M., \& Marbán, J. M. (2020b). Prospective teachers' online learning mathematics activities in the age of COVID-19: A cluster analysis approach. Eurasia Journal of Mathematics, Science and Technology Education, 16(9).

https://doi.org/10.29333/EJMSTE/8 345

Mustakim, M. (2020). Efektivitas Pembelajaran Daring Menggunakan Media Online Selama Pandemi Covid-19 Pada Mata Pelajaran Matematika. Al Asma: Journal of Islamic Education, 2(1), 1. https://doi.org/10.24252/asma.v2i1. 13646
Purnama, G. (2020). Comparison of Junior High School Student Mathematics Learning Results Between Students Who Learned Using Whatsapp Group Media With Students Which Learning Using Google Classroom MEdia In Pandemic Time Covid-19. Journal of Educational Experts, 3(2), 6973.

Reinhardt, J. (2019). Social media in second and foreign language teaching and learning: Blogs, wikis, and social networking. Language Teaching, 52(1), 1-39.

Susilowati, E. (2021). Comparison of WhatsApp and Google Classroom Group Online Learning Models to Student Learning Outcomes. Journal of Medives: Journal of Mathematics Education IKIP Veteran Semarang, 5(1), 61. https://doi.org/10.31331/medivesve teran.v5i1.1436

Suteja, B. R., Guritno, S., Wardoyo, R., \& Ashari, A. (2011). Personalization Sistem E-Learning Berbasis Ontology. MAKARA of Science Series, 14(2), 192-200. https://doi.org/10.7454/mss.v14i2.7 38

Wargadinata, W., Maimunah, I., Dewi, E., \& Rofiq, Z. (2020). Student's Responses on Learning in the Early COVID-19 Pandemic. Tadris: Jurnal Keguruan Dan Ilmu Tarbiyah, 5(1), 141-153. https://doi.org/10.24042/tadris.v5i1. 6153

Wiratomo, Y., \& Mulyatna, F. (2020). Use of Learning Management Systems in Learning Efforts during a Pandemic. Journal of Mathematical Pedagogy (JoMP), $1(2), 62-71$. 